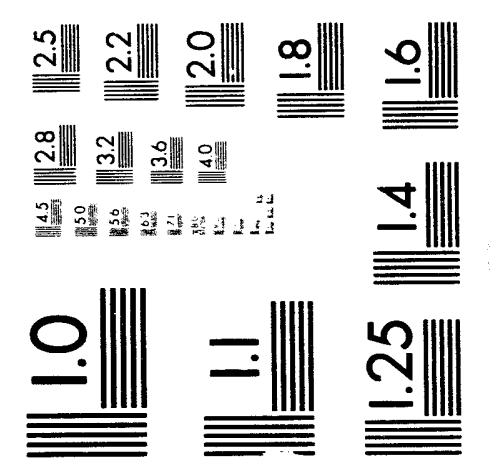



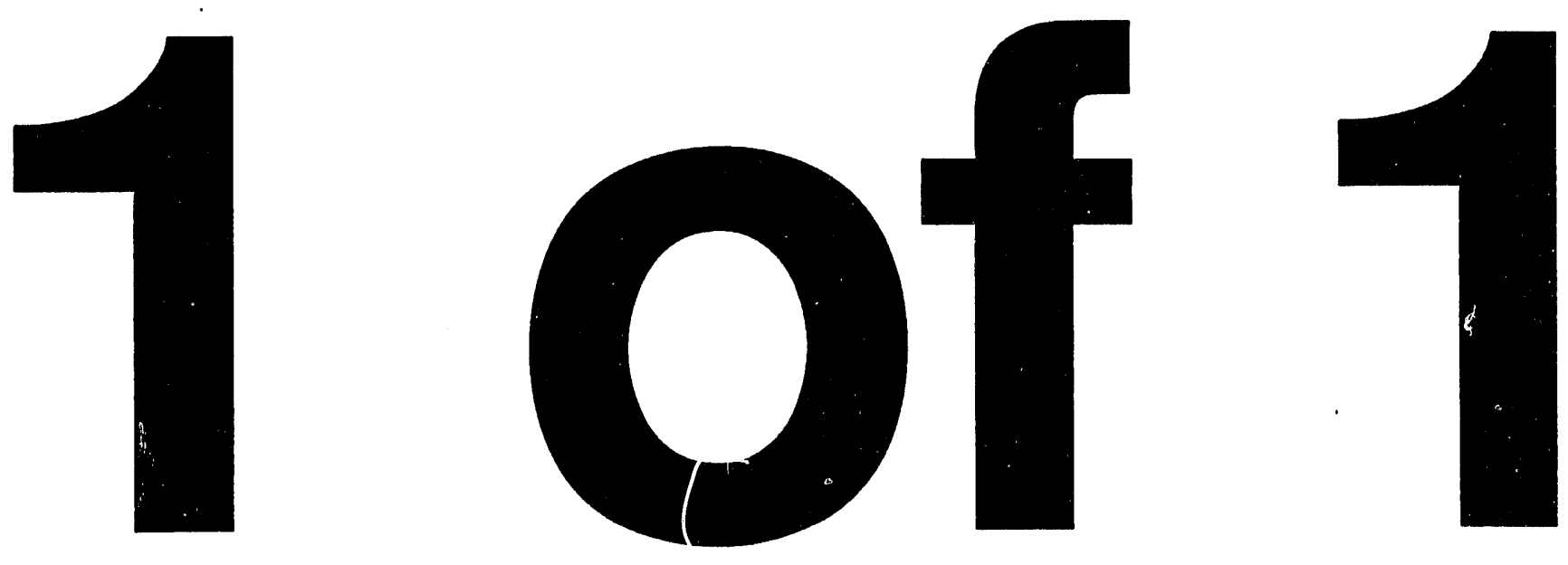


\section{Trends in Actinide Processing at Hanford}

Prepared for the U.S. Department of Energy

Office of Environmental Restoration

and Waste Management

\section{(2) Westinghouse \\ Hanford Company Richland, Washington}

Hanford Operations and Engineering Contractor for the

U.S. Department of Energy under Contract DE-AC06-87RL10930

Copyright License By acceptance of this article, the publisher and/or recipient acknowledges the U.S. Government's right to retain a nonexclusive, royalty-free license in and to any copyright covering this paper. 


\title{
Trends in Actinide Processing at Hanford
}

\author{
H. D. Harmon \\ Date Published \\ September 1993 \\ To Be Presented at \\ Actinides-93 International \\ Conference \\ Santa Fe, New Mexico \\ September 19-24, 1993
}

Prepared for the U.S. Department of Energy

Office of Environmental Restoration

and Waste Management

$\begin{array}{ll}\text { Westinghouse } & \text { P.O. Box } 1970 \\ \text { Hanford Company } & \text { Richland, Washington } 99352\end{array}$

Hanford Operations and Engineering Contractor for the

U.S. Department of Energy under Contract DE-AC06-87RL10930

Copyright License By acceptance of this articie, the publisher and/or recipient acknowledges the U.S. Government's right to retain a nonexclusive, royatty-tree license in and to any copyright covering this paper. 
LEGAL DISCLAIMEFI

This report was prepared as an account of work sponsored by an agency of the United States Government. Neither the United States Government nor any agency thereot, nor any of their employees, nor any of their contractors, subcontractors or the ir employees, makes any warranty, express or implied, or assumes any legal liability or responsibility for the acciracy, completeness, or any third party's use or the results of such use of any information, apparatus, product, or process disclosed, or represents that its use would not intringe privately owned rights. Reterence herein to any specific commercial product, process, or service by trade name. trademark, manufacturer, or otherwise, does not necessarily constitute or imply its endorsement, recommendation, or favoring by the United States Government or any agency thereof or its contractors or subcontractors. The views and opinions of authors expressed herein do not necessarily state or reflect those of the United States Government or any agency theriot.

This report has been reproduced from the best available copy.

Printed in the United Slates of America

OISCLM.2.CHP (1.91) 


\title{
TRENDS IN ACTINIDE PROCESSING AT HANFORD
}

\author{
by
}

Dr. H. D. Harmon, Vice President Tank Waste Remediation System Westinghouse Hanford Company

P. O. Box 1970

Richland, Washington

presented to

Actinides-93

International Conference

September 19-24, 1993

Santa Fe, New Mexico 


\section{TRENDS IN ACTINIDE PROCESSING AT HANFORD}

\section{INTRODUCTION}

In 1989, the mission at the Hanford Site began a dramatic and sometimes painful transition. The days of production--as we used to know it--are over. Our mission officially has become waste management and environmental cleanup. This mission change didn't eliminate many jobs--in fact, budgets have grown dramatically to support the new mission. Most all of the same skilled crafts, engineers, and scientists are still required for the new mission. This change has not eliminated the need for actinide processing, but it has certainly changed the focus that our actinide chemists and process engineers have.

The focus used to be on such things as increasing capacity, improving separations efficiency, and product purity. Minimizing waste had become a more important theme in recent years and it is still a very important concept in the waste management and environmental cleanup arena. However, at Hanford, a new set of words dominates the actinide process scene as we work to deal with actinides that still reside in a variety of forms at the Hanford Site. These words are repackage, stabilize, remove, store and dispose. Some key activities in each of these areas are described below. 


\section{REPACKAGING}

Irradiated Fuel

Chemical processing of nuclear fuel at Hanford is over. The PUREX plant shut down in 1987 and is currently focusing on planning for terminal cleanout. We still have irradiated nuclear fuel stored in Hanford reactor basins and it is not in a suitable form for long-term storage. A significant program is underway at K-Basin to encapsulate spent $N$ Reactor fuel, much of which shows evidence of cladding failure and attack on the fuel core. After encapsulation, it will be safe for long-term storage.

\section{Transuranic Waste}

Another key actinide-containing material that must be repackaged is TRU waste. It is estimated that $856 \mathrm{~kg}$ of plutonium is stored as solid waste at Hanford in various forms and storage modes. A facility is being resigned to "process" TRU waste in preparation for shipment to the Waste Isolation Pilot Plant. The Waste Receipt and Processing facility (WRAP-I) is scheduled for startup in March 1997. It will carry out the functions of nondestructive examination/assay, repackaging of TRU containers, and volume reduction. 


\section{STABILIZATION}

The Plutonium Reclamation Facility and Remote Mechanical "C" line at Hanford's Plutonium Finishing Plant have been shut down since 1989. However, plutonium residues continue to be stored in the plant. Some material in the plant can't be safely placed in storage vaults in its present condition because it is "reactive."

Plutonium residues--about 650 containers of liquids, sludges, powders and rages-have accumulated in short-term storage. The sludges and rays are presently stored in gloveboxes. The liquids are either in tanks in the Plutonium Reclamation Facility processing building or in vented storage containers in rooms in the Plutonium finishing Plant. This reactive inventory comprises approximately $9 \%$ of the total number of containers of Special Nuclear Materials in the Plutonium Finishing Plant. DOE wants to stabilize this material so it can be properly stored, thereby improving safety at the plant.

The Plutonium Reclamation Facility and the Remove Mechanical "C" Line convert plutonium solids and liquids to a stable oxide powder. This is accomplished by dissolution of the scrap materials, recovery and purification by solvent extraction using tributyl phosphate in carbon tetrachloride and plutonium (IV) oxalate precipitation. The existing process is the only one demonstrated on a scale large enough to meet requirements for the near-term stabilization program. This process is well understood and has been used at the Plutonium Finishing Plant for many 
years. It results in releases of carbon tetrachloride to the air and produces a large volume of liquid waste.

A wide range of new processes has been evaluated that could provide advantages over the existing processes. Theoretically at least, two of these processes--direct denitration and plutonium (III) oxalate precipitation--could decrease some effluents and byproducts. However, both processes would require additional development and some pilot plant operations and would delay stabilizing the material for several years. Thus, the current plan is to proceed with existing processes and convert the scrap to stable oxide as soon as possible.

For future campaigns involving other residues, a process using silver (II) is being studied. The silver (II) is generated by mixing silver nitrate and potassium persulfate in nitric acid. Dissolved plutonium [present as plutonium (VI)] is then reduced to plutonium (IV), more potassium ion is added, and potassium plutonium sulfate $\left[\mathrm{K}_{4} \mathrm{Pu}\left(\mathrm{SO}_{4} \mathrm{I}_{4} \bullet 2 \mathrm{H}_{2} \mathrm{O}\right)\right]$ is precipitated. This double salt can be dried for safe storage.

\section{REMOVAL}

Tank Waste Remediation System - New Technical Strategy

Removal of actinide elements is a key and important part of various pretreatment options being considered for Hanford's high level liquid waste. 
The previous Hanford high level waste program dramatically changed in the last two years. A new technical strategy has been proposed based on a 15 -month rebaselining study.

The proposed new technical strategy for managing the tank waste will focus first upon the mitigation or resolution of tank safety issues and the establishment of safety and environmental basis envelopes for continued operatioris. The tank farm infrastructure will also be upgraded to compliance with today's standards using a graded approach. Also, a major new project to construct new double-shell tanks to support tank safety issue resolution and to be reused for future disposal will proceed.

The new strategy for processing waste and managing system-generated waste addresses early progress towards disposal by initiating retrieval of supernatant and/or saltcake. Then, the waste is processed for radionuclide removal through either distributed compact processing units or a centralized pretreatment module. For the more difficult sludge waste, two bounding alternative technologies (extensive separations and large-capacity vitrification) will be developed in parallel until sufficient technical data are available for the decisionmakers to select a disposal approach. As the two bounding alternative technologies are developed and evaluated, an optimized alternative technology may develop that is between the two approaches and uses an intermediate level of separations and an appropriately sized vitrification facility. The future of the Hanford Waste Vitrification Plant will be 
determined when the total technical path forward is clear enough for decisionmakers to commit.

\section{Advanced Separations}

Laboratory-scale studies with washed solids are in progress to determine the applicability of processes such as selective leaching of actinide and fission products, leaching chromium and aluminum, and selective precipitation. More aggressive pretreatment technologies are being evaluated for deployment at a later date. Lab-scale studies with actual waste are proceeding to determine the susceptibility of single-shell tank sludges to dissolution by various chemical agents. Lab-scale studies are being conducted to evaluate solvent extraction for actinide removal as well as alternate processes such as ion exchange, precipitation, and extraction chromatography. Studies at Pacific Northwest Laboratory are investigating both TRUEX and diamides for actinide extraction.

Laboratory studies are underway at Argonne National Laboratory on a process that consolidates actinide, Cs and Sr removal into a single solvent extraction process. Combinations of TRUEX solvent locty (phenyl)N, Ndiisobutylcarbamoylmethylphosphine oxidel, tributyl phosphate, and crown ethers in n-paraffin hydrocarbon are being tested. The main focus of current work is to find combinations of extractants that do not adversely affect the selectivity and capacity of the others and to identify effective scrubbing and 
stripping agents. Non-phosphate stripping agents that decompose when heated are being evaluated.

\section{The Calcination/Dissolution Apprcach}

Plasma heating has been proposed to calcine the Hanford high levil waste at about $850^{\circ} \mathrm{C}$. A pilot-scale calcine demonstration has been performed with promising results using synthetic wastes simulating 101-SY slurry. The objectives of calcination are to:

- Destroy organic materials and ferrocyanide salts that may be present in the waste.

- Convert salts such as nitrate and nitrite to the corresponding oxides/hydroxides.

- Use the sodium hydroxide present in the high level waste and produced via calcination/dissolution as a fluxing agent to solubilize part of the sludges.

At the end of calcination, the high level waste will be essentially a molten solution of metal oxides, aluminates, silicates, phosphates, sulfates and chlorides in a sodium hydroxide solvent.

In the dissolution step of the calcination/dissolution process, the sodium hydroxide-based solid solution will be treated with water. The key to the 
calcination/dissolution approach is the assumption that the transuranic elements (specifically, neptunium, plutonium and americium) will stay water insoluble and thus be present in a relatively small voluıne of metal oxide/hydroxide sludge remaining for long-term immobilization in glass. The water-soluble phase, containing the short-lived fission products, would be pretreated as required and processed into a low-level waste form such as grout.

\section{Soil Washing}

Significant quantities of plutonium-contaminated liquids were discarded to the soil during the previous decades of Hanford's operation. Cleanup of these plutoniumcontaminated waste sites is currently being studied.

Soil washing/separation processes have been used for many years in sand and gravel and mining operations, removing unwanted materials by washing, and concentrating a desired particle size or mineral. These systems have been used successfully in Europe for environmental purposes and are being studied in the United States for use in remediating past practice waste sites selected for inclusion on the Environmental Protection Agency (EPA) National Priorities List (EPA, 1989). Soil washing demonstrations under the DOE Office of Technology Development are planned at Fernald (Uranium) and Nevada (Plutonium). 
Laboratory data and preliminary indications from field treatablity tests conducted in FY 1993 in the North Process Pond of the 300-FF-1 Operable Unit at Hanford indicate that physical separation/soil washing could reduce the volume of uranium contaminated soils in that area by $90 \%$ or more.

A modified EPA soil washing system was used for these tests. The system consists of a hopper, a vibrating screen, and high pressure spray bar to wash and eliminate material $>25 \mathrm{~mm}$ in diameter, a belt convayor, a trommel with high pressure water knives to wash and screen material $>2 \mathrm{~mm}$ in diameter, a second vibrating screen to separate particles $>0.425 \mathrm{~mm}$, fractionation tanks to contain effluent and serve as settling tanks, and an off-line water treatment process.

Laboratory tests are in progress to assess the feasibility of treating 100 Area soils. Primary contaminants of concern include: ${ }^{60} \mathrm{Co},{ }^{152 / 154} \mathrm{Eu}$, and ${ }^{137} \mathrm{Cs}$. Treatment of soils containing low concentrations of ${ }^{90} \mathrm{Sr}$ and ${ }^{238 / 240} \mathrm{Pu}$ from a crib in the $100-\mathrm{F}$ area will also be assessed. Results of these tests will be presented at the next Environmental Restoration Conference, ER'93. Treatability studies of surface contaminated soils in the 200 Area are also being considered. Some chemical extraction work for plutonium in soils has been conducted at Hanford's Plutonium Finishing Plant. 


\section{STORAGE AND DISPOSAL}

Ultimately, this actinide processing function will transition to a storage and disposal mode for materials as follows:

- Encapsulated fuel (N Reactor, FFTF, etc.)

- Stabilized plutonium solids

- Vitrified high level waste awaiting shipment to a federal repository

- Transuranic waste to Waste Isolation Pilot Planc

The facility requirements for these functions should not be uriderestimatid. An engineering study has pr sposed a Multi-Purpose Storage Complex (MPSC) to fulfill many of these functions. Note in an artist's conception the future vitrification plant is dwarfed by the storage and material handling facilities that have been envisioned. The future of this project is still under evaluation. 


\section{CONCLUSIONS}

Much actinide processing remains to be done at Hanford. However, the focus has shifted to repackaging, stabilizing, removing, storing and disposing of actinidebearing materials. While different than historical trends in actinide processing, the processing requirements are very challenging indeed.

One of the most challenging requirements is waste minimization. We cannot afford to generate significant quantities of new waste, and we must all remember the Universal Law of Waste Management -- "It gets bigger every time you touch it." 


\section{Trends in Actinide Processing at Hanford Site}

Presented by

Dr. Harry D. Harmon

Vice President

Tank Waste Remediation System

Westinghouse Hanford Company

HANFORD Actinides-93 - September 1993 


\section{Trends in Actinide Processing at Hanford Site}

- Repackaging

- Stabilization

- Removal

- Storage

- Disposal 


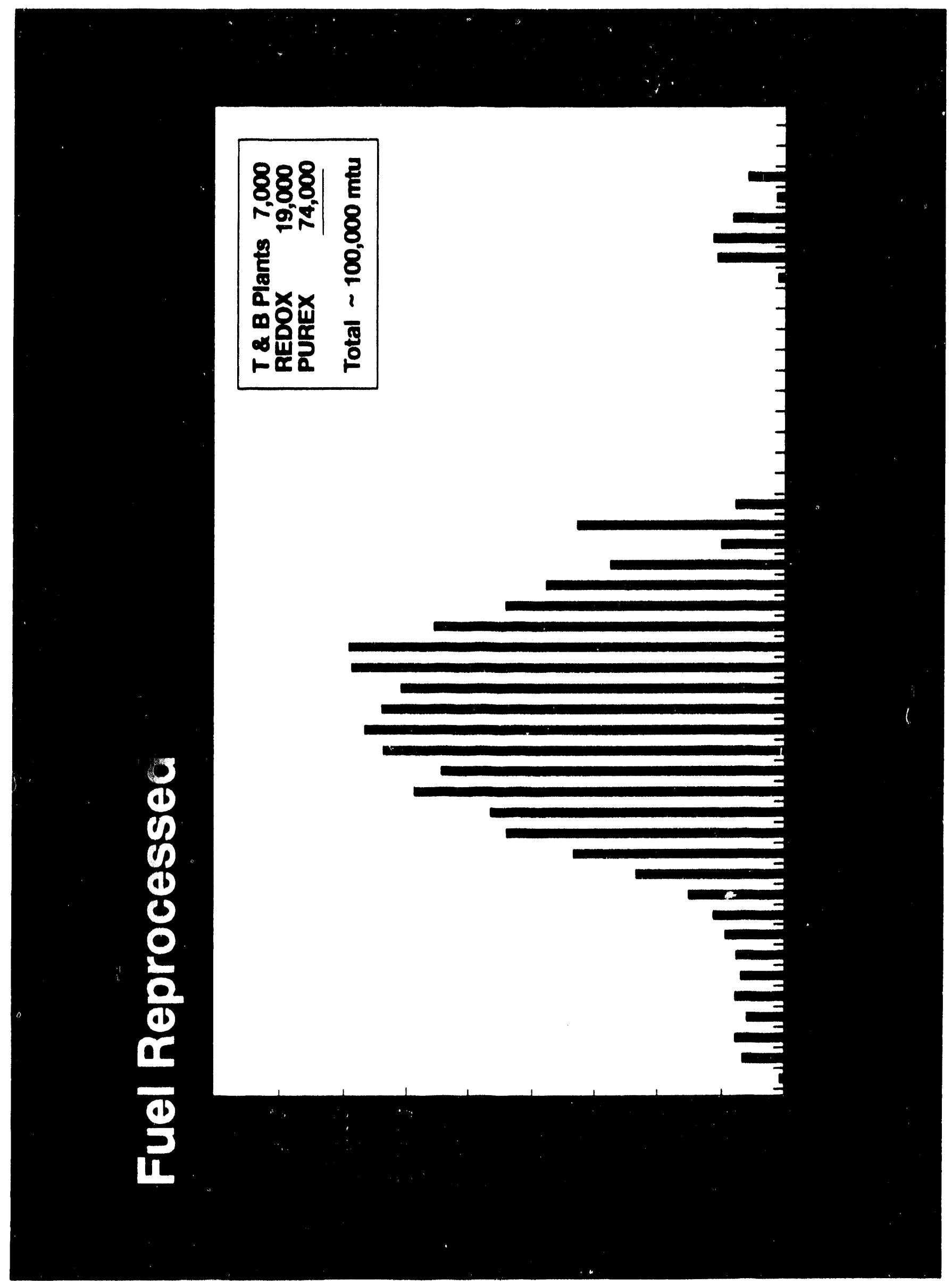




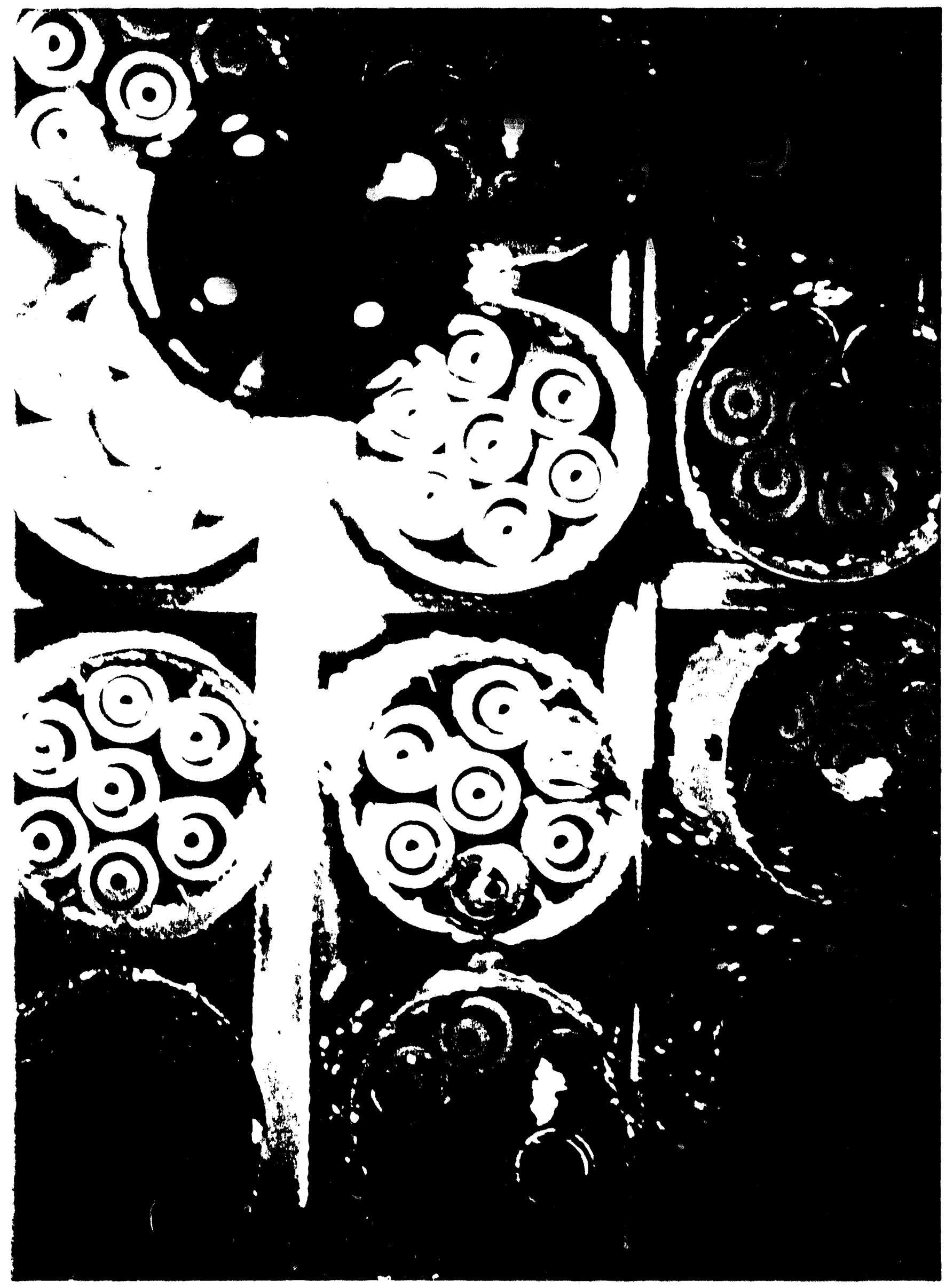




\section{Encapsulation}

2 Each fuel element is manually transported to repackaging station using counter-flotation fuel tongs.

1 Fuel elements are emptied onto table.

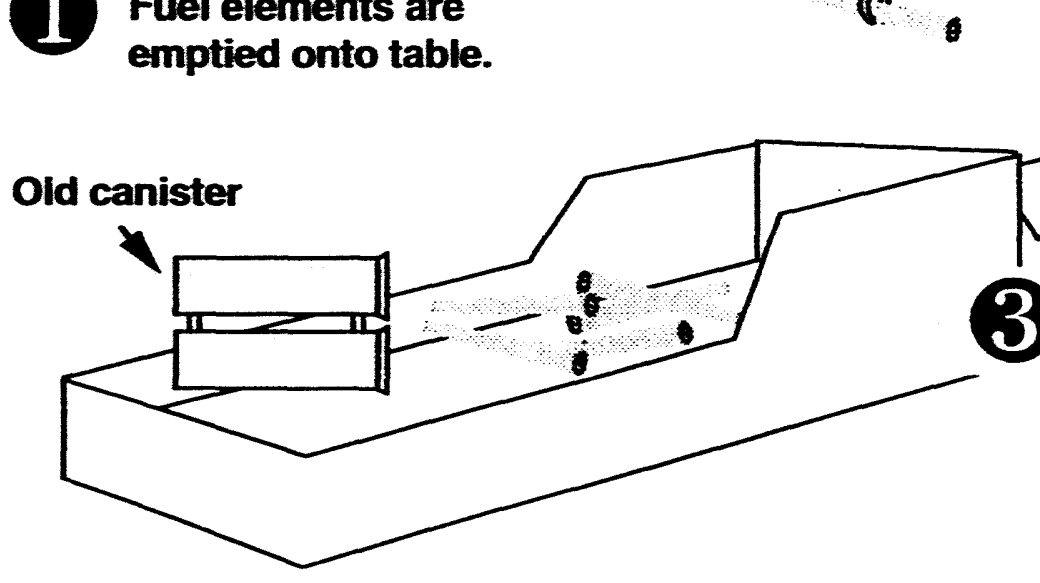

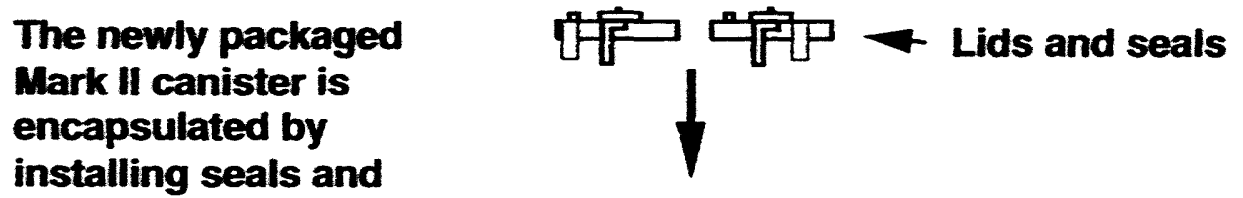
lids. An inhibitor is injected, and the canister is purged with nitrogen.
5

Canister is
ready to be
moved to its
basin storage
rack.

Canister is ready to be basin storage rack.

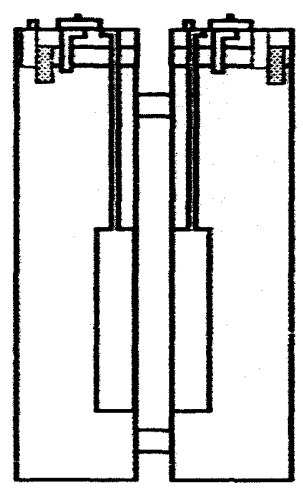

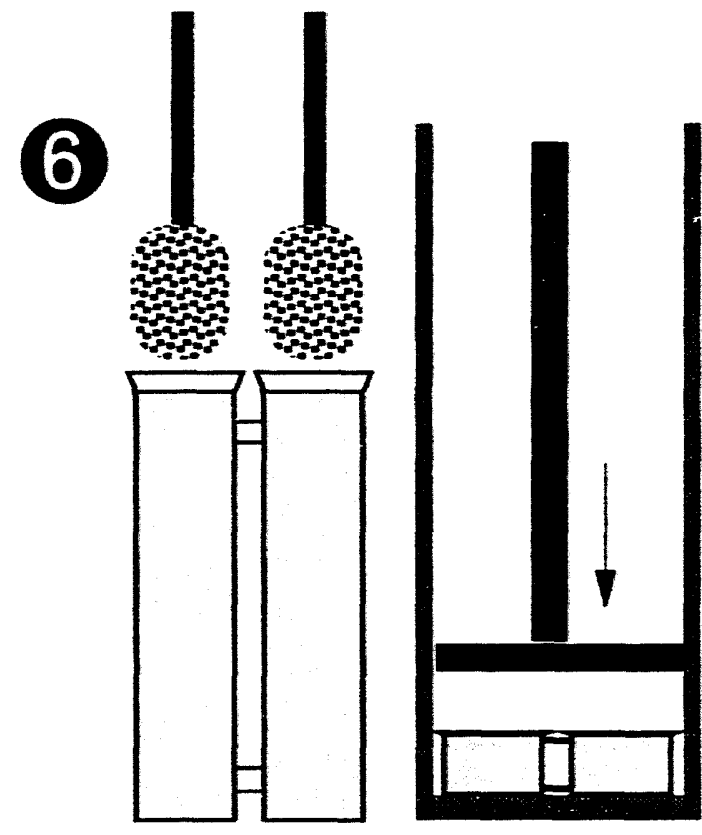

Emptied canister is cleaned and crushed. Crushed canister is removed from basin and packaged for disposal. 


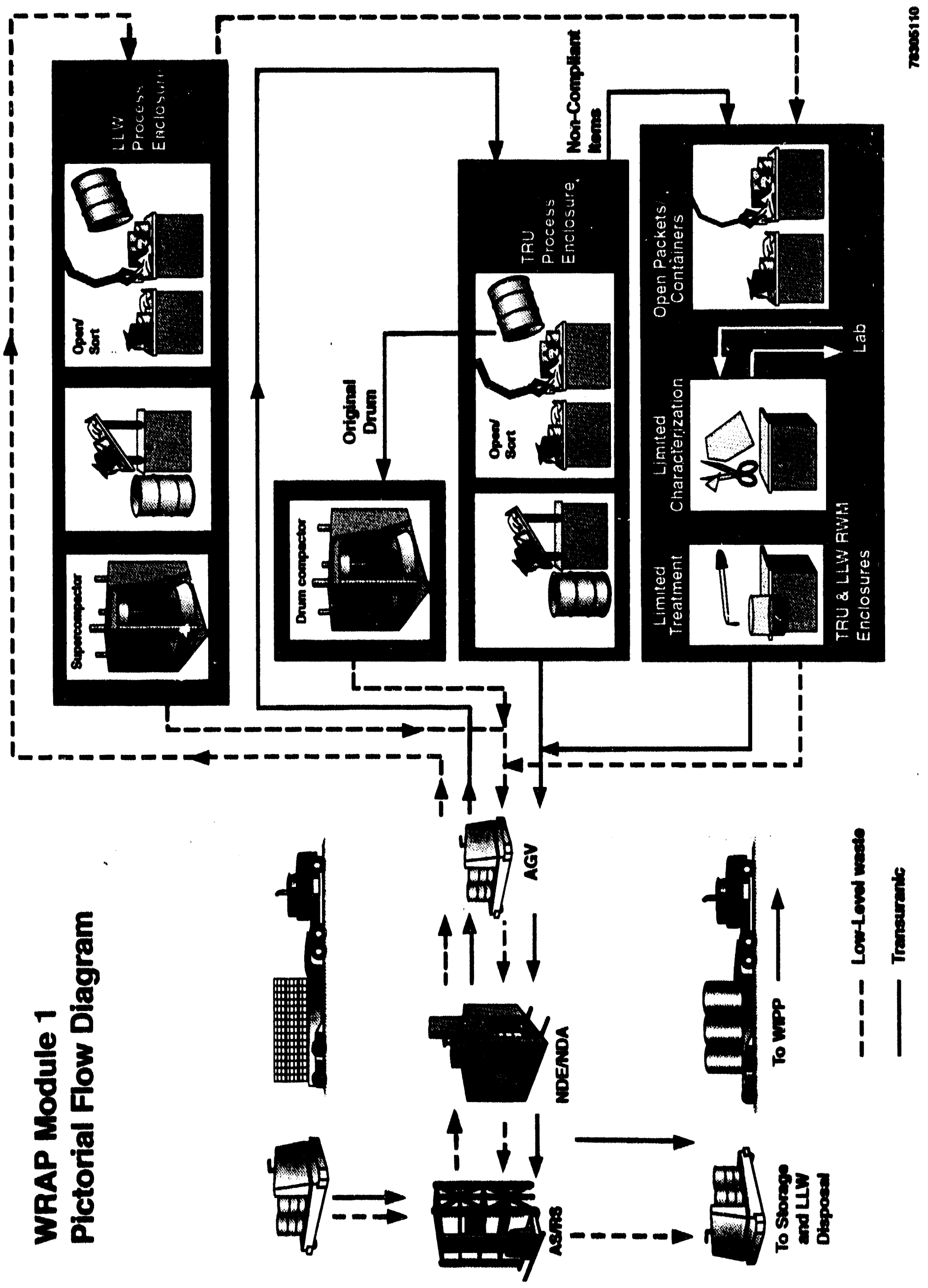


-. Metwitwan has wors cescturatod, or the Romote Mechanical " $\mathrm{C}$ " line,

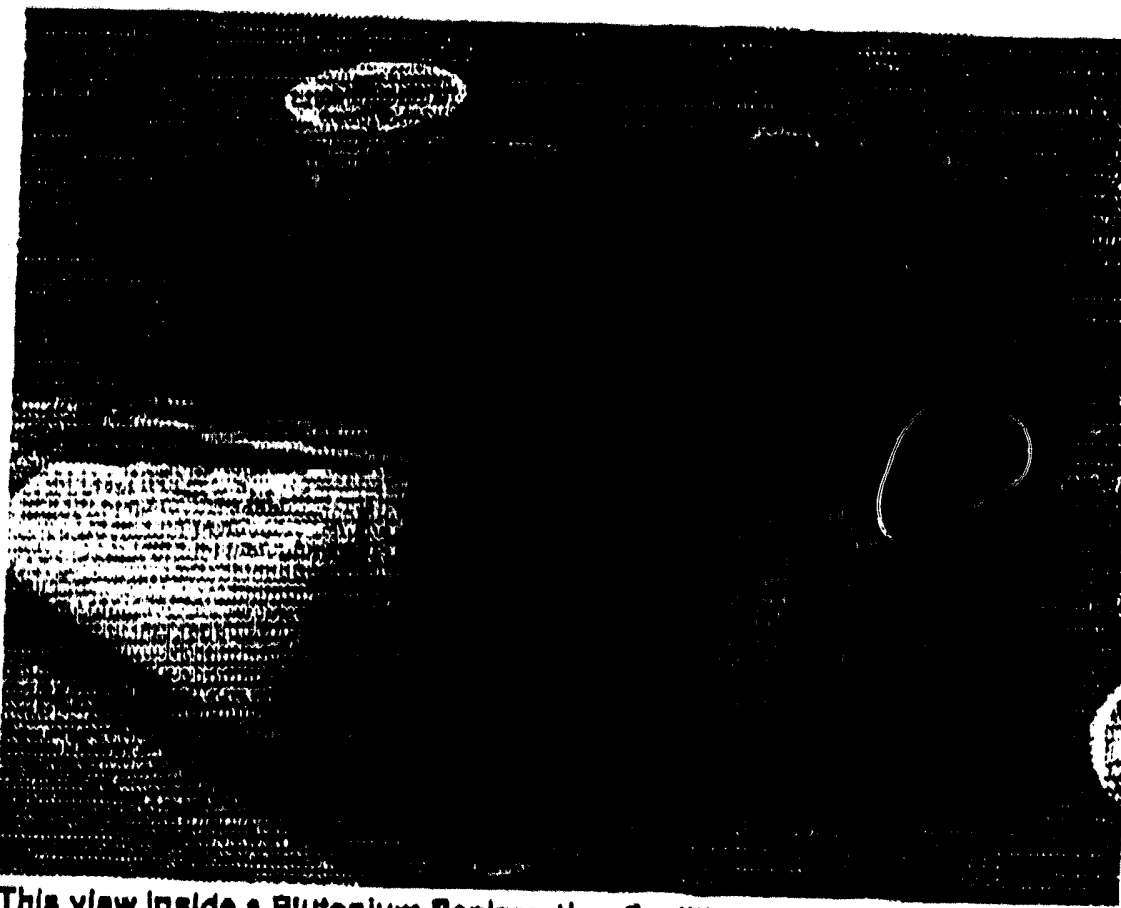

This viow Inalde a Plutonlum Reclamition Pacllity glovobox shows ox amples of plutonlum rosiduos in storago. Plutonium-bearing serap is containad in the canlster. The rag in the foreground la aleo contaminated
with plutonlum. 
1988 Hanford Defense Waste - Environmental Impact Statement Baseline Basis for Current Tri-Party Agreement

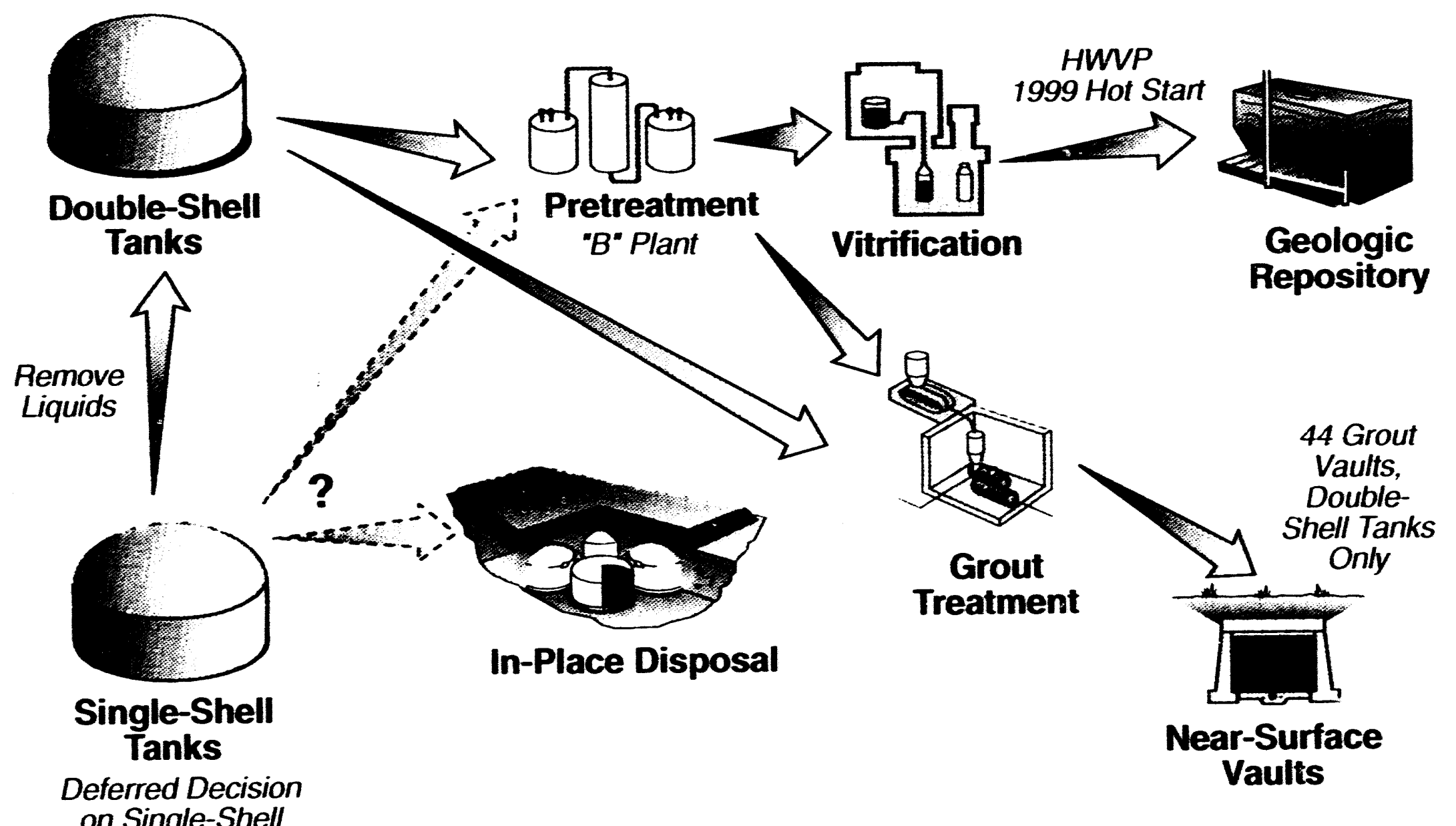

Public Irwolvement Rev. Date 5/13/93 29108013.1C 


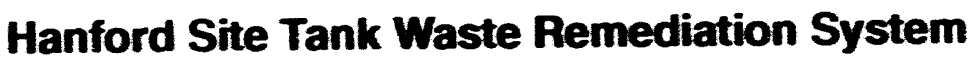 What has Changed?}

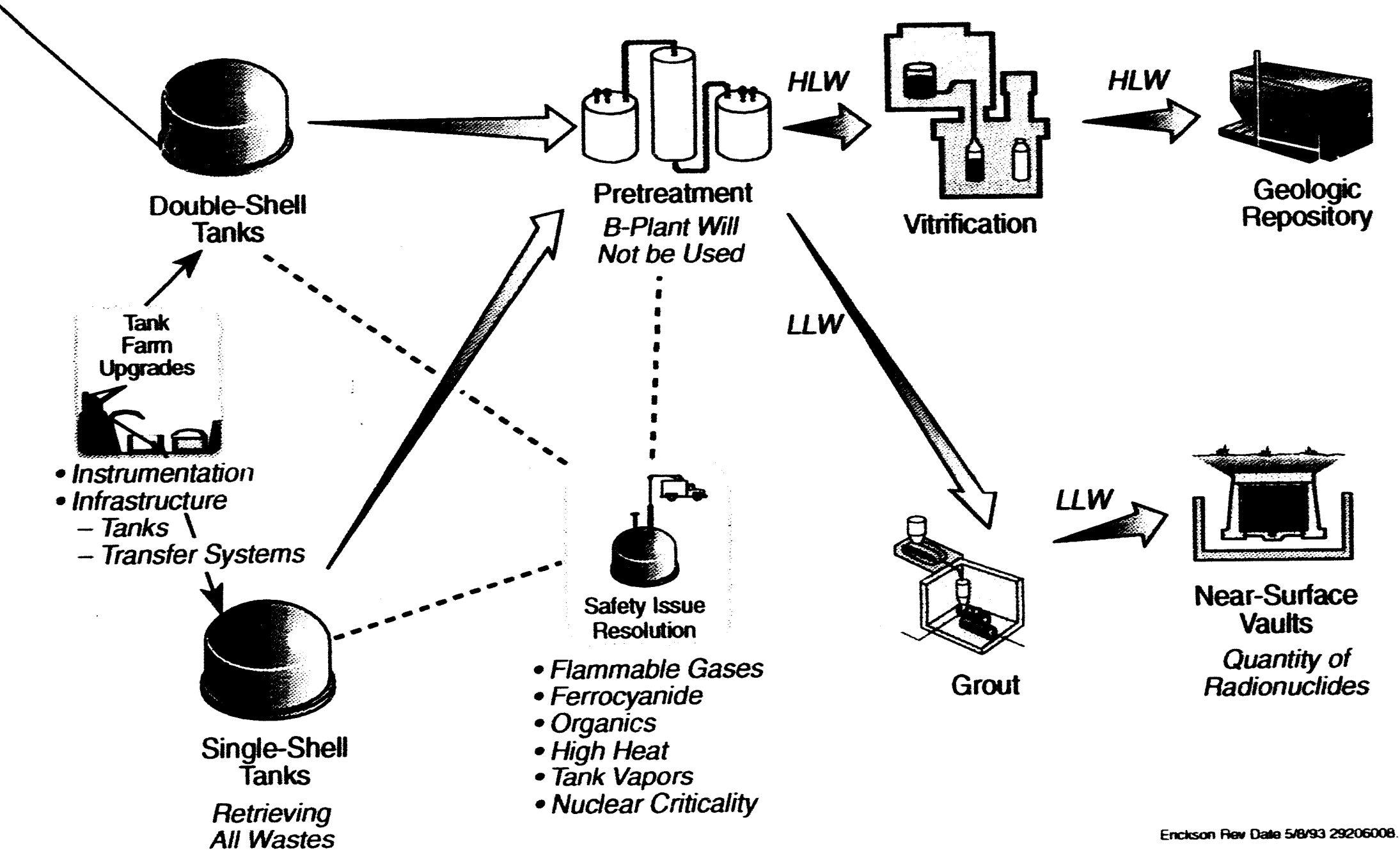




\section{Proposed New Technical Strategy}

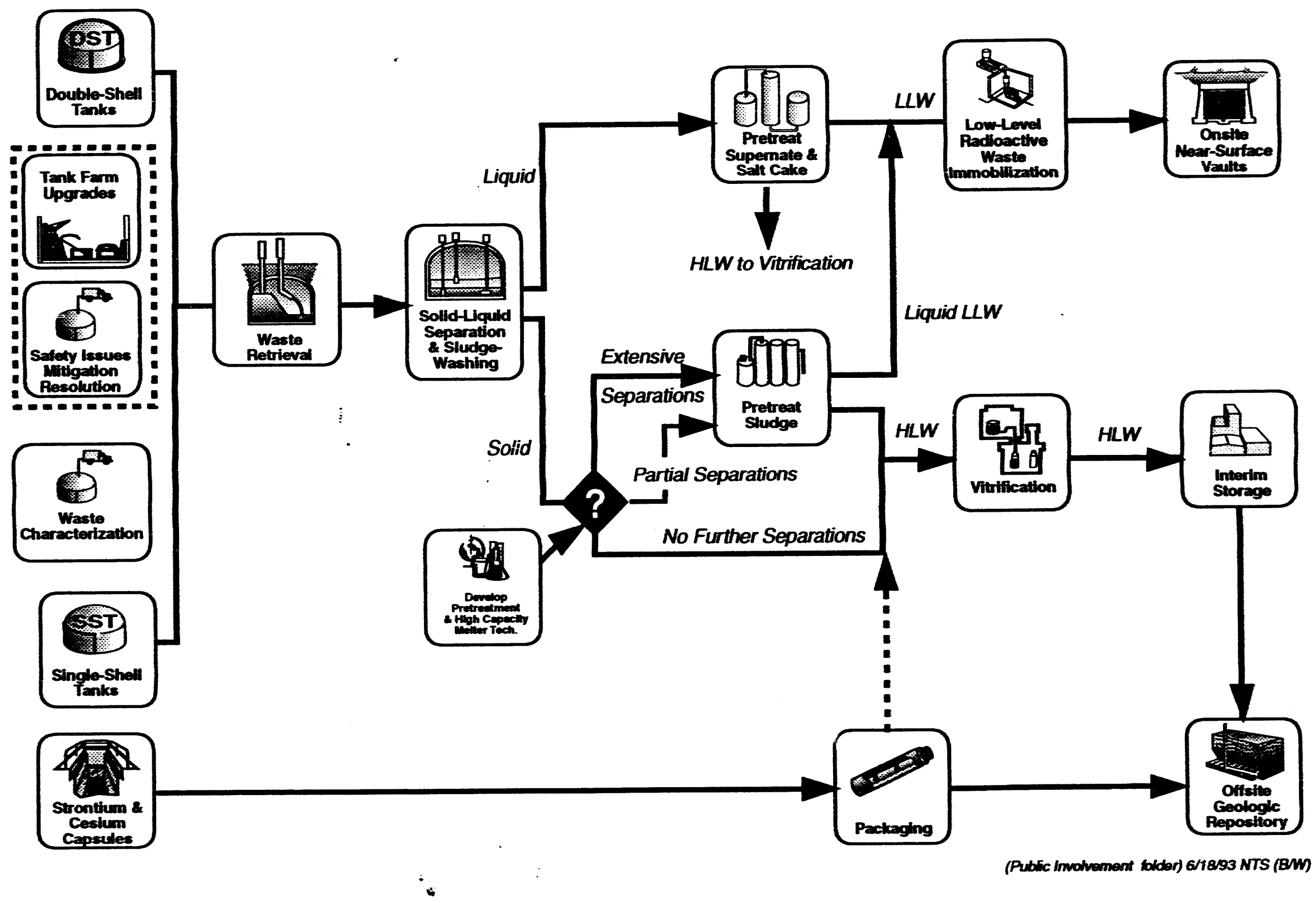




\section{Technical Alternatives for Pretreatment Strategy}

\begin{tabular}{|l|l|}
\hline Alkaline Processes & Acidic Processes \\
\hline \hline Organic/FeCN Destruction & \\
\hline Sludge Washing (Solubles) & Sludge Dissolution \\
\hline Selective Sludge Leaching (Al, Cr) & Actinide Removal \\
\hline Cesium Removal & Cesium Removal \\
\hline Technicium Removal & Technicium Removal \\
\hline Strontium Removal & Strontium Removal \\
\hline Calcination/Dissolution & lodine Removal \\
\hline Chemical Recycle & Chemical Recycle \\
\hline
\end{tabular}




$$
2
$$

\section{Waste Management 'gs}

\section{Waste Calcination Procese}






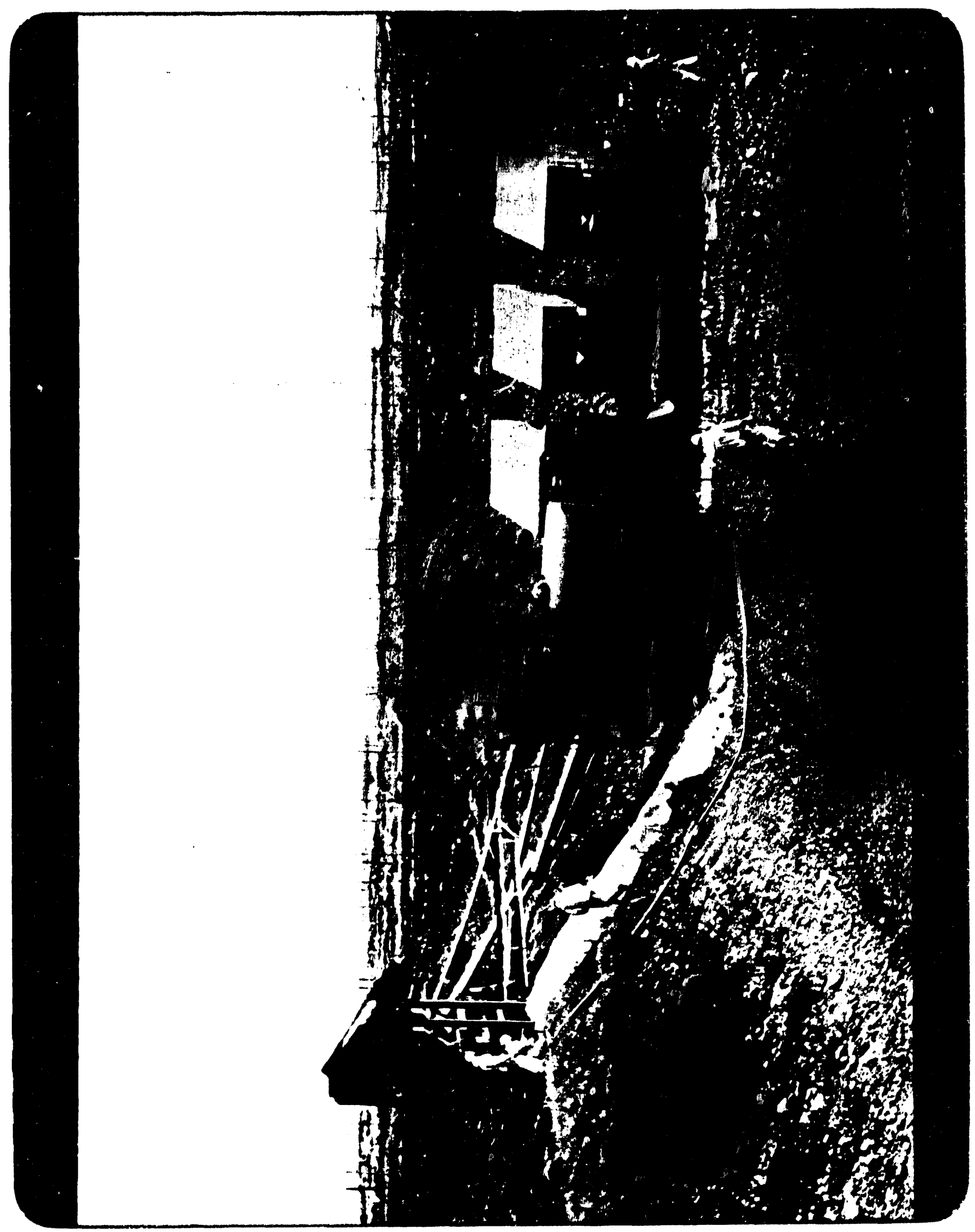




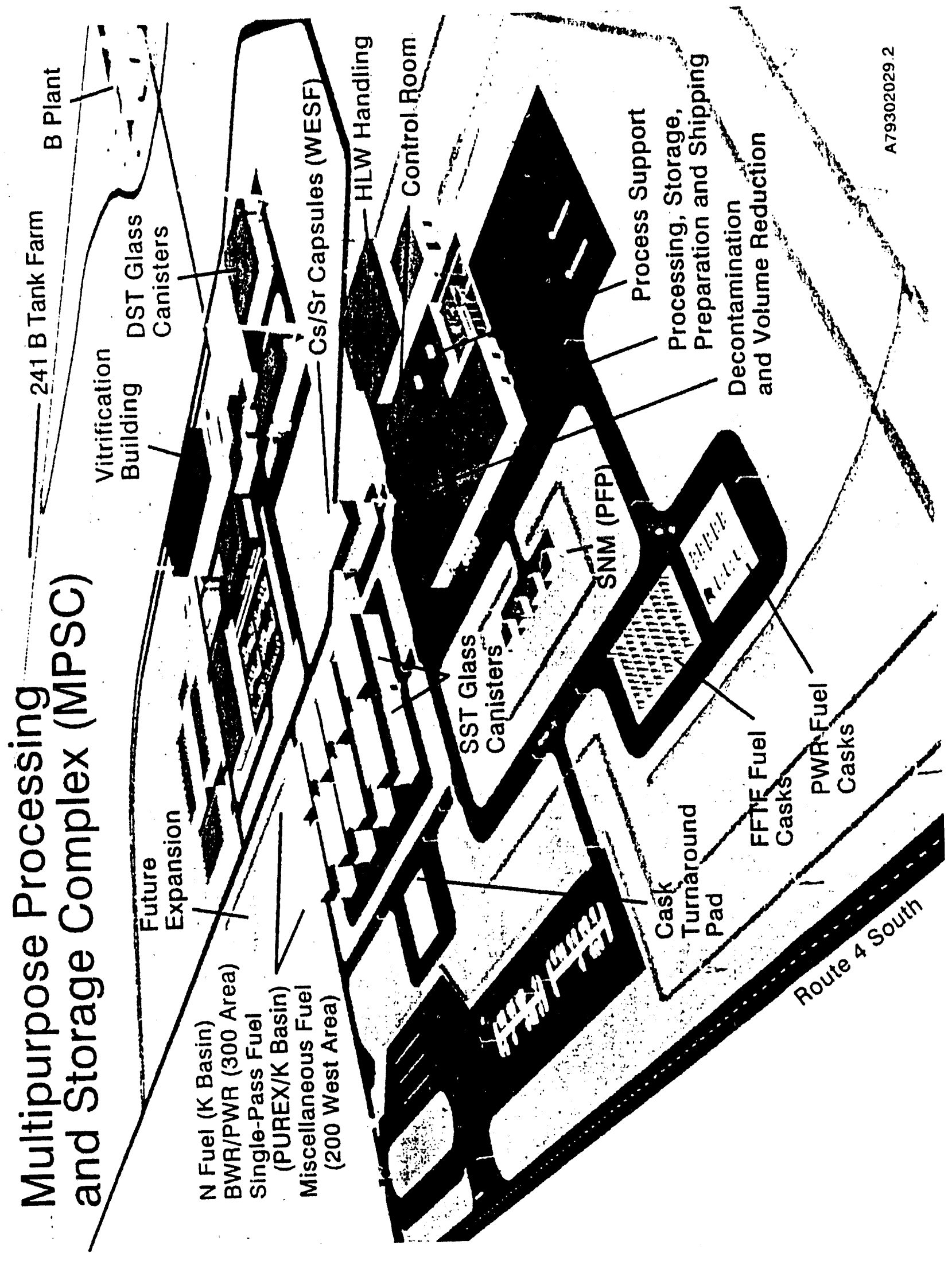




\section{Conclusion}

- Focus of actinide processing has made a major change

- Waste minimization is critical

- Many challenges remain 

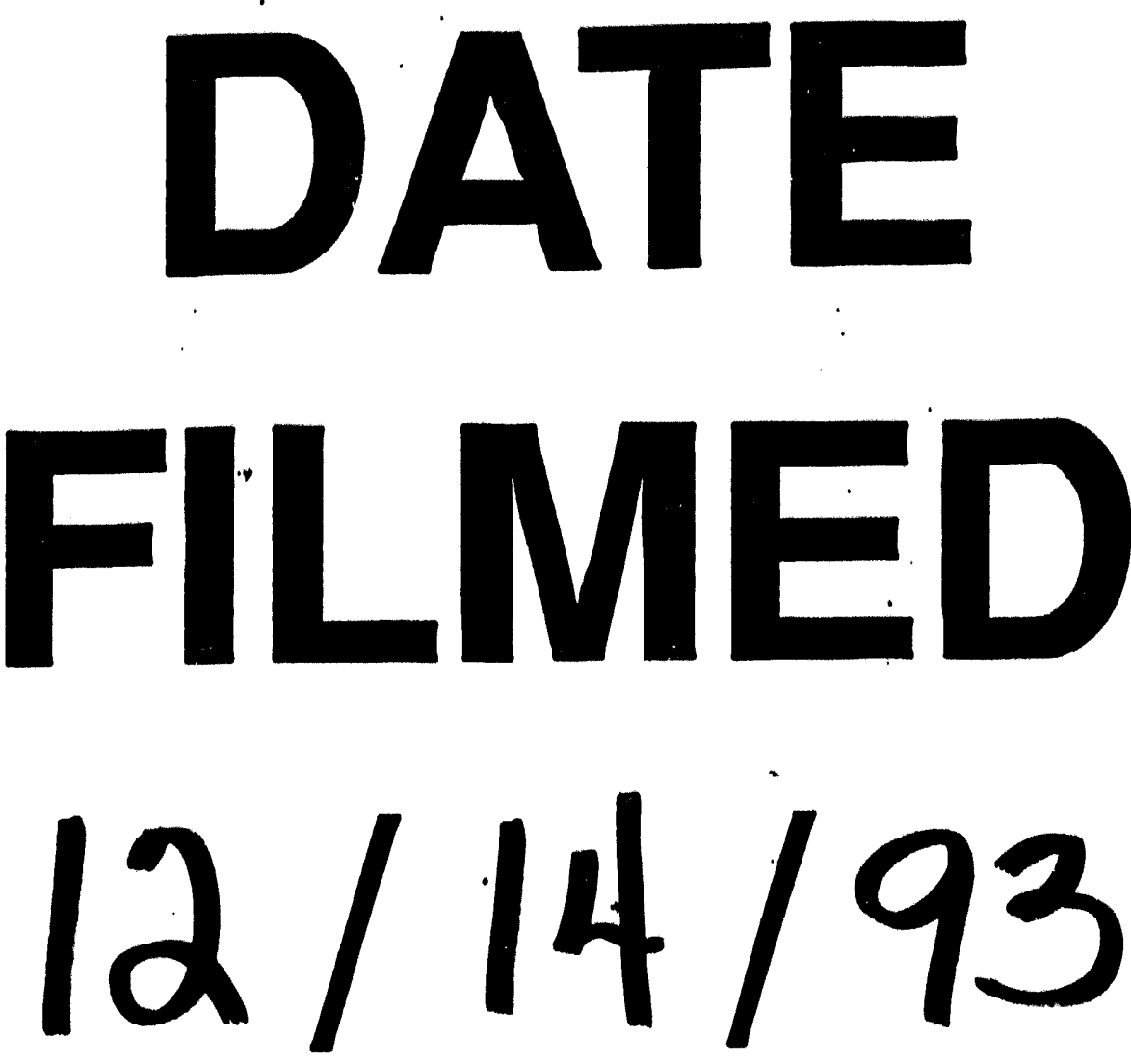

93
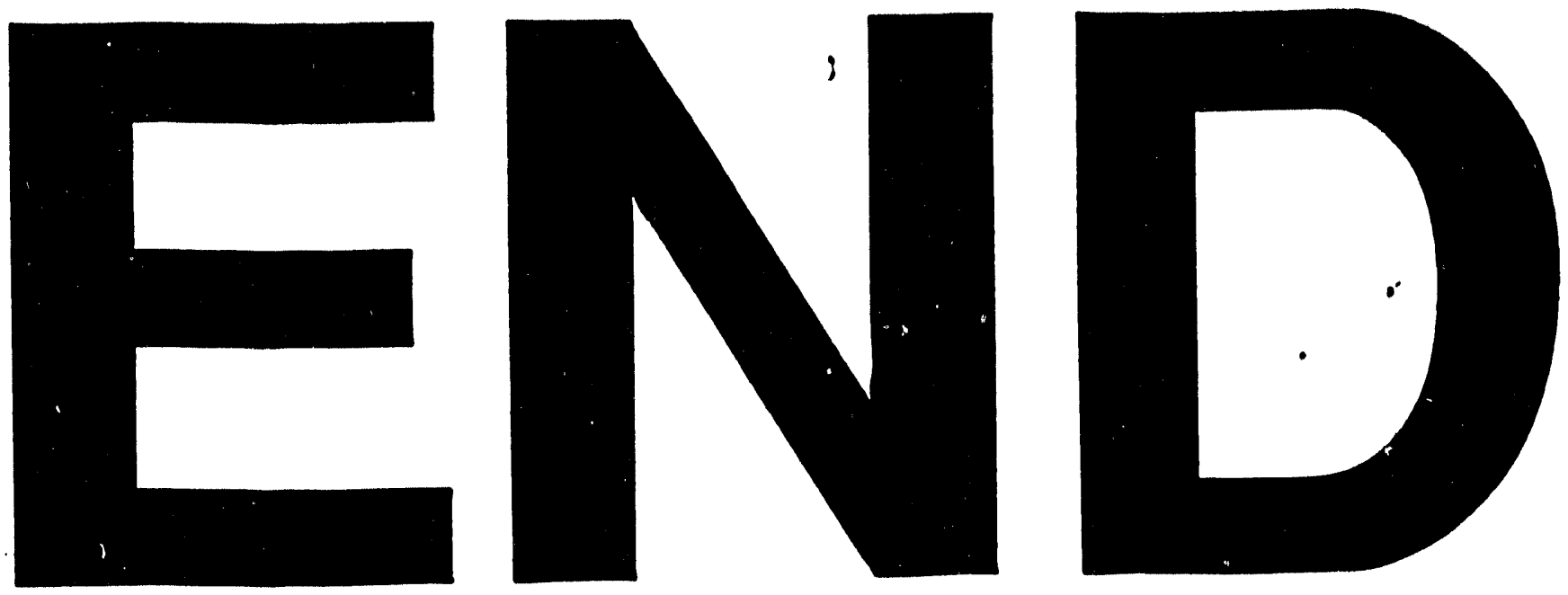
<smiles>C=C</smiles>

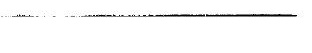

